\title{
The Impact of Sarbanes Oxley 404 Exemption on; Non-accelerated filers, Investor's Confidence, And External Audit Fees
}

\author{
Osama Omar Jaara (Corresponding Author) \\ Associate professor of Accounting, American University of Madaba, Jordan \\ Email: o.jaara@aum.edu.jo
}

\begin{abstract}
Maen Reda Oweis
Associate professor of Accounting, American University of Madaba, Jordan

Email: maenoweis@gmail.com
\end{abstract}

Received: January 21, 2015 Accepted: January 29, 2016 Published: April 17, 2016

doi:10.5296/ijafr.v6i1.8911 URL: http://dx.doi.org/10.5296/ijafr.v6i1.8911

\begin{abstract}
This study adds on prior studies that have examined SOX 404 effect on external audit fees, internal controls and financial restatements. The paper examined the outcomes of Dodd-Frank Act that have exempted non-accelerated filers from SOX 404 (B). Where through this paper it has been assumed that this Act has decreased SOX 404 compliance costs on non-accelerated filers, and it also suggested that this Act did not have any negative effects on the effectiveness of the internal controls for these companies. After performing a correlation analysis on this assumption the results turned out to be consistent with what was previously assumed. Where the correlation results indicated that external audit fees for non-accelerated filers had declined, and the internal controls deficiencies count showed a constant declining trend. The paper examined also the extent to which investor's confidence has been enhanced through the implementation of SOX 404. The assumption that was assumed in this paper was that; when a restatement is announced the amount of demand on that company's share will decline resulting in a decrease in the share price. The results of the correlation analysis that was performed on this assumption showed that after implementing SOX 404 the financial restatements announcements stopped to have the same negative effect on share prices, in relation to the before implementation period. The finding that led to the conclusion that SOX 404 has successfully enhanced investors' confidence.
\end{abstract}

Keywords: SOX 404, Dodd-Frank Act, SOX 404 B, external audit fees, internal 
controls deficiencies, financial restatements announcements, investors' confidence.

\section{Introduction}

Starting from the point where publicly traded companies began to collapse in the United States due to massive accounting scandals that have been committed by large publicly traded companies "Like WorldCom in 2000, Enron in 2001, Global Crossing in 2002"; with the conspiracy with some major auditing firms like Arthur Anderson (Iliev 2010). These massive accounting scandals have forced the United States congress to consider tighter legislations that would minimize the possibility of such scandals from happening again (SOX-online, 2003). In addition to that they also wanted to regain investors' lost confidence in published financial statements (Nysscpa, 2006).

As an outcome of these concerns, in the summer of 2002 Sarbanes Oxley Act (SOX) was issued with two main goals and eleven different titles. The first main perceived goal behind this eleven titles Act; is to restore investors' lost confidence in publicly traded companies, and secondly it mainly aims to improve the quality of internal controls and enhance the transparency of the financial reporting mechanism. SOX aims to achieve these goals by mainly; ensuring auditor's independence, holding management liable for their published results, governing the reporting process through an independent body, and also applying sufficient internal controls that will minimize the possibility of material misstatement, or fraud from occurring (GRCG, 2003).

Out of these eleven titles, SOX 404 was the most controversial one, where in 2002 when it was signed by President Gorge Bush. He described it as "the farthest reaching reforms Acts of the American business practices since the time of Franklin Delano Roosevelt" (FED-SOC, 2002).

Through this enhancement, this research paper will attempt to examine the possible effects that the count of reported financial restatements has on investor's confidence for the period before and after implementing SOX 404. Since announcing a restatement on an issued financial statement is perceived as a negative indicator about the effectiveness of the internal controls system of the issuing company. This issue may encourage investors to question the reliability of the issued financial statements. And when investors have doubts about the issued financial results; they would react in a negative manner which will be reflected on the financial market earnings. Where when the number of financial restatements increases, investor's doubt will also increase, and when investor's scepticism increases; their intention to trade would decrease; which will eventually result in decreasing the financial market profitability, since their demand for that company's share will decrease (Mccrary, 2010).

In support to this outcome, a study was conducted by the Governmental Accounting Office (GAO) in 2009depicting the effects of restatements on financial markets for the period from 1997 until 2006. As a result of these financial restatements it has been noted that a loss of almost $\$ 100$ billion in the overall market value has been recorded after the announcement of these restatements (GAO, 2009).

On the basis of the pervious discussion, this research will have the following main questions. 
Q1 How did exempting non-accelerated filers from complying with SOX 404 (B) requirements have affected external audit fees, and internal controls deficiencies count?

Q2 To what extend has the implementation of SOX 404 minimized the negative outcomes of financial restatements announcements; in term of investor's confidence; in comparison to the before implementation period?

In relation to the earlier proposed questions, this research paper will mainly attempt to meet the following main objectives in the conclusion section:

1) To determine to what extent has SOX 404 achieved its main goals.

2) To critically examine and evaluate the cost benefit of exempting non-accelerated filers from complying with SOX 404 (B) requirements in terms, of the amount of reported internal controls deficiencies, material weaknesses, and external audit fees.

3) To evaluate how has investor's reactions changed towards the announcements of financial restatements for the period before and after implementing SOX 404.

\section{Literature review}

\subsection{SOX 404 brief history overview}

SOX 404 originally included two main parts; the first part which is known as SOX 404 (A), is concerned about the management's responsibility for maintaining effective internal controls. The second part that is known as SOX 404 (B) requires from the company's independent auditor to assess and state their opinion about the extent to which management has designed and maintained effective internal controls.

When SOX 404 was first implemented it became obvious that the amount of internal controls information communicated to investors has increased, as well as external audit fees. Since complying with SOX 404 standards required enormous amount of time, and attention in terms of documentation, and testing of internal controls. According to a study conducted by Financial Executives International (FEI) in March 2005, on 217 publicly traded companies, it was concluded that an average of almost 26,758 extra internal labour hours were required to comply with SOX 404 requirements. In addition to that, almost 94 percent of the companies which have participated in this survey have recognized that the cost of implementing SOX 404 outweighed its benefits (Brounstein, 2005). In relation to that, another study was conducted by Price water house coopers $(\mathrm{PwC})$, where it has been found, after conducting a survey on 136 publicly traded companies, that the compliance cost of SOX 404 has almost been doubled from 32 percentage increase to almost 60 percentage since it was enacted in 2003 (Nysscpa, 2009).

SOX 404 compliance requirements have servility affected non-accelerated filers, where they complained that they are more adversely affected from the implementation of SOX 404 (B) requirements than any other filer. They also claimed that the SEC has severely underestimated the amount of hours needed from external auditors to evaluate the effectiveness of internal controls. This has resulted in increasing the amount of external audit 
fees to unexpected levels. So as a response to these massive compliance expenses proponents of small sized companies communicated these concerns to the SEC.

In 2007 the PCAOB provided some guidance which would help external auditors to scale their assessment process of companies' internal controls effectiveness. Which will give external auditors the opportunity to conduct their audit in a more efficient and effective manner, which would also result in lowering SOX 404 (B) compliance cost for non-accelerated filers (SEC, 33-8810).

Despite the PCAOB efforts things did not change much, where a lot of non-accelerated filers were still suffering from the high compliance expenses of SOX 404 (B). So in the same year "2007" the SEC made a second attempt to ease the suffering of non-accelerated filers by granting them a temporary exemption from complying with SOX 404 (B). This temporary exemption continued for almost three years, then in 2010 the Dodd-Frank legislation requested from the SEC to change the temporary exemption to a permanent one, since the dissenting opinions of this Act has started to decrease. So as a response for this positive outcome; on the 21st of July 2010 President Barak Obama changed this exemption to be as a permanent exemption for non-accelerated filers (KPMG, 2010).

\subsection{Debate around SOX 404}

There is a growing amount of literature that has examined the outcomes of SOX 404. Some of these studies have discussed the relationship between internal controls deficiencies and external audit fees. Through which they have found that there is a negative correlation between these two variables; through which it has been concluded that having tighter internal controls would lead to lower external audit fees (Raghunandan, and Rama, 2006); since the effectiveness of internal controls would be directly reflected on the degree of control risk in the company. From the other hand, it has been found that there is a positive correlation between external audit fees and the level of audit risk, and control risk. Where lower control risk means lower audit risk, and having lower audit risk results in smaller audit scope, which eventually leads to lower audit fees (ACCA, 2009).

In 2008, Hogan and Wilkins have found that external audit fees in the year before disclosing an internal control deficiency were much lower than the fees that companies would have to pay in the coming periods (Hogan, and Wilkins, 2008). Furthermore, in a similar empirical study Hoitash and Bedardin (2008), has found that external audit fees may fluctuate according to the severity of the reported material weaknesses. This means that if a company has incurred significant restatements due to material weaknesses in internal controls the result would be more external audit fees (Hoitash and Bedardin, 2008). In a similar study by Raghunandan and Rama in 2006, it has been found that after only one year of implementing section SOX 404 the average external audit fees have increased by almost 86 percent (Raghunandan and Rama, 2006). Other studies have concluded that the biggest portion of the compliance cost would be due to the upfront costs that are paid out to meet SOX requirements, For example; increasing the number of internal auditors to ensure the effectiveness of internal controls is maintained (Primack, 2007). 
Despite the fact that, SOX 404 has been investigated a lot in different papers. There are a very small amount of papers that have examined the effect of exempting non-accelerated filers form SOX 404 (B). According to a study by Feng and Li in 2011, it has been found that this outcome will have a direct negative effect on the U. S. economy. Since non-accelerated filers form the vast majority of listed companies in the U. S. financial market (Feng and Li, 2011). Furthermore, it has been found that these requirements where sometimes preventing emerging companies from going public. Moreover, some small sized companies have even disregarded future, or present growth opportunities, so they would avoid the compliance burden of SOX 404 (B). Through the GAO's study it has also been noticed that complying with SOX 404 requirements have affected manager's behaviour. Where it has been found that, some managers would prefer to take conservative actions in their investment decisions in order to keep their companies in the non-accelerated filers' category. Since complying with SOX 404 (B) requirements would result in increasing the non-value adding spending in terms of money and time (GAO, 2009).

Another study was conducted by Holder, Karim and Robin in 2013 about the outcomes of Dodd-Frank permanent exemption Act. Where, the exemption matter raised a lot of questions about whether permanently exempting non-accelerated filers was a premature step or not (Holder, Karim and Robin, 2013). Where it has been found that, in the period before granting the permanent exemption to non-accelerated filers, the reporting quality was much better, the matter which have raised concerns about the opportunity cost of this Act.

\subsubsection{Debate around SOX 404 effect on investor's confidence}

Despite the massive amount of literature that have examined the outcomes of SOX 404; Bedard's study in 2006 is considered as one of the well-known empirical studies that have examined the outcomes of SOX 404 requirements on internal controls. Where he have found that, companies which have complied with SOX 404 requirements started to report a lower amount of unexpected accruals in comparison to the pre-compliance period, the matter that have resulted in enhancing the quality of earnings. Furthermore, in the same empirical study Bedard (2006) have also found that the overall earnings quality has improved in periods where deficiencies in internal controls have been disclosed. The outcome that have led to the conclusion, that for the period after implementing SOX 404 internal controls requirements; the earnings quality for companies which started to comply with SOX 404 began to improve (Bedard, 2006). In 2010, Nagy has extended Bedard (2006) study in to two main important areas. As mentioned earlier one of the indicators that Bedard (2006) used to measure the earnings quality; was the amount of unexpected accruals. Where he assumed that effective internal controls increases the earnings quality, which eventually decreases the unexpected accruals. Then in the second section of his study; Bedard (2006) has considered the outcomes of SOX 404 regulations on the earnings quality after only the first year of complying with SOX 404, where he also used the unexpected accruals as an indicator (Bedard, 2006). On the other hand, Nagy (2010) has measured the financial reporting quality by considering the count of material misstatements reported. Where, he assumed that the count of material misstatements would directly reflect any massive internal controls deficiencies, the measure which will give a better indication about the benefits of complying 
with SOX 404 requirements. The second main difference between these two studies is that Nagy, in 2010 has considered SOX 404 compliance outcomes for several periods after the compliance year, the indicator which helped him to make a better assessment about the extent to which SOX 404 has enhanced the reporting quality (Nagy, 2010).

Another study has examined the benefits of SOX 404 implementation was performed by Qian et al in 2010, where they have found that accelerated filers have enjoyed better economic outcomes than small sized companies. Furthermore, they have noticed that after SOX 404 implementation CEOs compensations has been reduced, intentional budgetary slacks has been minimized, and the complying companies even got an easier access to public funds (Qian, Strahan and Zhul, 2010).

On the other hand, Thornton in their study in 2013, have found that the matter of disclosing material weaknesses would directly affect investor's investment decisions. So investors will have higher expectation of earnings from companies which did not disclose any weakness in their internal controls. Moreover, they have found that the expected future earnings from companies that have disclosed a material weakness in their internal controls over financial reporting would be lower, than companies which did not disclose any material weaknesses (Thornton, and He, 2013), A study by Bonkim et al in (2013), has found that undisclosed internal controls weaknesses have a positive relationship with the risk of the share price. This means that if a company discloses internal control weaknesses the share risk involved in decreasing the share price will increase (Bonkim, Yeung and Zhou, 2013). Furthermore, studies have investigated the consequences of the outcomes of control risks, where it has been found that companies which have reported a weakness in their internal controls will most likely perform a restatement, the matter that is consistent with the relationship between internal controls weaknesses and the probability of performing a restatement.

As a result of all these different studies it can be concluded that internal controls quality have a direct positive relationship with the quality of financial reporting, which would eventually have a direct effect on the financial market movement (Rice and Weber, 2011).

Furthermore, some recent studies have also empirically examined the effects of financial restatements' on financial markets movement. Through which it has been found that the effects of restatements on the financial market has changed in the period after SOX Act has been enforced. Through which it has been found that the severity of the financial restatements has become less severe than before. The matter that may indicate that investor's trust may be getting stronger (Scholz, 2008). In addition to Scholz's 2008 study, Turley and Howe in 2012 have almost reached the same conclusion, where they have found that after almost ten years of implementing SOX 404, the effectiveness of internal controls has been enhanced and investor's lost confidence have been regained because of the enhanced transparency of information communicated to them (Turley and Howe, 2012).

\section{Methodology}

This research paper will be based mainly on secondary quantitative data. This data will be analysed using the Pearson's correlation analysis method. In the methodology and data 
analysis section there will be a more detailed description about the method used to analysis data.

One of the main differences between this paper and the other papers; is that this study will consider all the previously mentioned factors as constant besides one factor which is the level of complexity in internal controls. Where, this paper assumes that there is a direct positive relation between the level of internal controls complexity that a company has and the amount of time that external auditors has to spend on understanding these controls, which from the other hand would have a direct effect on the external audit fees. Where the more complicated the company's internal controls are; the more time external auditors would devote to constructively evaluate these controls, therefore the external audit fees would increase. On the other hand, the simpler the company's internal controls are the less time external auditors would spend on evaluating them, which should lead to lower external audit fees.

The main reason behind considering this factor only and holding the other factors constant is that, with the implantation of SOX 404 internal controls requirements; the complexity and the cost benefit of the newly designed internal controls became one of the most debatable outcomes of this Act. Where a vast amount of studies like; Raghunandan and Rama in 2006, Primackin 2007, Gao et al. in 2009, Holder, Karim and Robin in 2013; suggests that one of the major draw backs for implementing SOX 404 is the complications that it generates in terms of complying with its internal controls requirements.

The first main assumption in this study is stated below in its null form:

A1: The Dodd-Frank Act has benefited non-accelerated filers by decreasing their overall compliance expenses, without affecting the reliability their financial information.

The second assumption of this paper is stated below in its null form:

A2: Announcing a financial restatement has a direct negative effect on the company's share price, but after the implementation of SOX 404 this negativity should get lower.

\subsection{Data Used for the first Assumption:}

The data used to investigate the first assumption consists of a random sample from different filers which operate in different industries. The period from which these companies were selected from is between 2005 and 2010:

The selected data can be categorised in to three main categories;

1) Data about average annual audit fees per filer;

2) Annual change in the count of reported material weaknesses;

3) Annual change in the count of reported internal controls.

\subsubsection{Data gathered for the first assumption:}

The data gathered to analysis the first assumption has been randomly selected from two studies conducted by Audit Analytics. 


\section{Macrothink}

International Journal of Accounting and Financial Reporting

ISSN 2162-3082

2016, Vol. 6, No. 1

The first Audit Analytics study that is going to be used in this research paper was conducted on the $7^{\text {th }}$ of June 2010, where it has examined the outcomes of implementing SOX 404on non-accelerated filers, accelerated filers, and large accelerated filers (Audit Analytics, 2010).

From this Audit Analytics study this paper will use; the number of opinion filers who filed their statements to the SEC from 2005 until 2010.

The additional main factors that will be also considered are as following;

1) Personal Competence issues; identifies the count of encountered internal controls deficiencies that may have happened due to the lack of skills, or experience in the company's employees (Audit Analytics, 2010).

2) Segregation of duties; determines the degree of effectiveness of a company's internal controls that would prevent one employee of having too much authority and responsibility (Audit Analytics, 2010).

3) Financial restatements count; indicates the number of times a company had to restate its opinion in conformance with SOX 404; after the financial statements have been issued (Audit Analytics, 2010).

4) Material annual adjustments count; points out the volume of changes made in the issued financial reports which would have a direct effect on investor's decision(Audit Analytics, 2010).

5) Internal audit issues; indicates the situations where the internal audit department or functions are not operating in an effective manner and no corrective actions have been taken, when these internal controls deficiencies were noticed(Audit Analytics, 2010).

6) IT processing access issues; determines the level of security that the company has, that would prevent unauthorized access to its operating system from one hand, and from the other hand it determines the extent to which it has ensured a certain level of independence and authority between different departments (HOCK, 2010).

The second Audit Analytics survey was conducted on the $20^{\text {th }}$ of June 2012; where this survey points out the changes that happened on audit fees and non-audit fees, during the last ten years (Audit Analytics, 2012).

However, since this research paper focuses on SOX 404 (B) effect on audit fees; data about non-audit fees will not be used in this paper. At the same time, since this study will be joined with the earlier Audit Analytics study, some minor adjustments should be performed in order to maintain an acceptable level of reliability.

1) The first adjustment that is going to be done is a simple mathematical adjustment.

2) After figuring out the new adjusted annual audit fees, the percentage of change in the audit fees in each year should also to be considered, 
(Average audit fees in the second year-Average audit fees in the first year)

Average audit fees in the first year

3) At the same time since this study also considers SOX 404 effect on internal controls deficiencies and material weakness count. It will be illogical not to consider the same changes for both internal controls and for the material weaknesses count. In order to consider these changes the difference between the count of internal controls deficiencies and material weakness in two consecutive years will be taken and divided by the amount of the previous year as following.

(Internal controls count in second year - Internal controls count in first year)

Internal controls count in the first year

(Material Weaknesses count in second year-Material Weaknesses count in first year)

Material Weaknesses count in the first year

The below table gives some guidance about the changes that have been made in used data;

Audit fees adjustments;

\begin{tabular}{|l|l|l|l|l|l|l|}
\hline $\begin{array}{l}\text { Column } \\
\text { Number }\end{array}$ & 1 & 2 & 3 & 4 & 5 & 6 \\
\hline $\begin{array}{l}\text { Year of } \\
\text { complianc } \\
\text { e }\end{array}$ & $\begin{array}{l}\text { Num. of } \\
\text { Opinions } \\
\text { Filed in } \\
\text { study 1 }\end{array}$ & $\begin{array}{l}\text { Study 2 total } \\
\text { audit fees }\end{array}$ & $\begin{array}{l}\text { Num. } \\
\text { of } \\
\text { nsinio } \\
\text { Filed in } \\
\text { study } 2\end{array}$ & $\begin{array}{l}\text { Average } \\
\text { annual audit } \\
\text { fees }\end{array}$ & $\begin{array}{l}\text { Adjusted Audit } \\
\text { fees }\end{array}$ & $\begin{array}{l}\text { e Adjus } \\
\text { chang } \\
\text { ted } \\
\text { Audit } \\
\text { fees }\end{array}$ \\
\hline 2006 & 3,791 & $7,611,985,849$ & 2507 & $3,036,292.72$ & $11,510,585,701$ & \begin{tabular}{l}
0.11 \\
\hline 2007
\end{tabular} \\
\hline 2008 & 4,496 & $8,152,773,589$ & 2507 & $3,252,003.82$ & $14,621,009,197$ & 0.11 \\
\hline 2009 & 4,330 & $7,785,383,524$ & 2507 & $3,105,458.13$ & $13,446,633,689$ & $(0.08)$ \\
\hline 2010 & 3,356 & $7,646,749,555$ & 2507 & $3,050,159.38$ & $10,236,334,865$ & $(0.24)$ \\
\hline
\end{tabular}

Calculations made using columns number; 

a) Column 2/Column $3=$ Column 4
b) Column $1 *$ Column $4=$ Column 5
c) Column $6=(\mathrm{Y} 2-\mathrm{Y} 1) / \mathrm{Y} 2$

Internal controls and Material Weaknesses count before adjustments:

\begin{tabular}{|l|l|l|l|l|l|l|l|l|}
\hline $\begin{array}{l}\text { Yr of } \\
\text { compli } \\
\text { ance }\end{array}$ & $\begin{array}{l}\text { Num } \\
\text { Opin } \\
\text { ions } \\
\text { File } \\
\text { d }\end{array}$ & $\begin{array}{l}\text { Materia } \\
\text { Weakn } \\
\text { esses } \\
\text { Count }\end{array}$ & $\begin{array}{l}\text { Perso } \\
\text { nal } \\
\text { Issues }\end{array}$ & $\begin{array}{l}\text { Segreg } \\
\text { ation of } \\
\text { Duties }\end{array}$ & $\begin{array}{l}\text { financial } \\
\text { restatem } \\
\text { ents }\end{array}$ & $\begin{array}{l}\text { Material } \\
\text { Annual } \\
\text { Adjustm } \\
\text { ents }\end{array}$ & $\begin{array}{l}\text { Inter } \\
\text { nal } \\
\text { Audi } \\
\text { t } \\
\text { Issue } \\
\text { s }\end{array}$ & $\begin{array}{l}\text { IT } \\
\text { Process } \\
\text { ing, } \\
\text { Access } \\
\text { Issues }\end{array}$ \\
\hline 2006 & $\begin{array}{l}3,79 \\
1\end{array}$ & 390 & 207 & 57 & 177 & 250 & 4 & 79 \\
\hline 2007 & $\begin{array}{l}4,21 \\
6\end{array}$ & 382 & 179 & 50 & 126 & 260 & 14 & 74 \\
\hline 2008 & $\begin{array}{l}4,49 \\
6\end{array}$ & 347 & 226 & 47 & 77 & 233 & 12 & 90 \\
\hline 2010 & $\begin{array}{l}4,33 \\
0\end{array}$ & 211 & 124 & 26 & 52 & 138 & 12 & 58 \\
\hline
\end{tabular}

Internal controls and Material Weaknesses count after adjustments:

\begin{tabular}{|c|c|c|c|c|c|c|c|}
\hline & \multicolumn{6}{|c|}{ Internal Controls related factors } \\
\hline $\begin{array}{l}\text { Year of } \\
\text { complia } \\
\text { nce }\end{array}$ & $\begin{array}{l}\% \text { of } \\
\text { change } \\
\text { in } \\
\text { Materi } \\
\text { al } \\
\text { weakn } \\
\text { esses } \\
\text { count }\end{array}$ & $\begin{array}{l}\% \text { of } \\
\text { Chang } \\
\mathrm{e} \quad \text { in } \\
\text { Person } \\
\text { al } \\
\text { Issues }\end{array}$ & $\begin{array}{l}\% \text { of } \\
\text { change } \\
\text { in } \\
\text { Segregat } \\
\text { ion of } \\
\text { Duties }\end{array}$ & $\begin{array}{l}\% \text { of } \\
\text { change in } \\
\text { financial } \\
\text { restateme } \\
\text { nts }\end{array}$ & $\begin{array}{l}\% \text { of } \\
\text { change in } \\
\text { Material } \\
\text { Annual } \\
\text { Adjustme } \\
\text { nts }\end{array}$ & $\begin{array}{l}\% \text { of } \\
\text { chang } \\
\mathrm{e} \text { in } \\
\text { Intern } \\
\text { al } \\
\text { Audit } \\
\text { Issue } \\
\text { s }\end{array}$ & $\begin{array}{l}\% \text { of } \\
\text { change } \\
\text { in IT } \\
\text { Processi } \\
\text { ng, } \\
\text { Access } \\
\text { Issues }\end{array}$ \\
\hline
\end{tabular}




\begin{tabular}{|l|l|l|l|l|l|l|l|}
\hline 2006 & $(38 \%)$ & $(32 \%)$ & $(62 \%)$ & $(45 \%)$ & $(25 \%)$ & $\begin{array}{l}(76 \% \\
)\end{array}$ & $(41 \%)$ \\
\hline 2007 & $(2 \%)$ & $(14 \%)$ & $(12 \%)$ & $(29 \%)$ & $4 \%$ & $250 \%$ & $(6 \%)$ \\
\hline 2008 & $(9 \%)$ & $26 \%$ & $(6 \%)$ & $(39 \%)$ & $(10 \%)$ & $(14 \%$ & $22 \%$ \\
\hline 2009 & $(39 \%)$ & $(45 \%)$ & $(45 \%)$ & $(32 \%)$ & $(41 \%)$ & 0.00 & $(36 \%)$ \\
\hline 2010 & $(61 \%)$ & $(63 \%)$ & $(65 \%)$ & $(60 \%)$ & $(55 \%)$ & $(50 \%$ & $(60 \%)$ \\
\hline
\end{tabular}

\subsection{Data Used for the Second Assumption:}

The data used to investigate the second Assumption can be divided in to the following main parts;

1) A random sample of the annual count of financial restatements from 1997 until 2005;

2) Stock prices for thirty randomly selected companies from different industries throughout each year of the selected period;

3) The date of the restatement, stock price before one day of the restatement announcement, and after five days of the restatement announcement.

The table below demonstrates a summary of the used data:

\begin{tabular}{|c|c|c|c|c|c|c|c|c|}
\hline $\begin{array}{l}\text { Com } \\
\text { pany } \\
\text { Name }\end{array}$ & $\begin{array}{l}\text { Count } \\
\text { of } \\
\text { Restate } \\
\text { ment }\end{array}$ & $\begin{array}{l}\text { Restate } \\
\text { ment } \\
\text { Type }\end{array}$ & $\begin{array}{l}\text { Restate } \\
\text { ment } \\
\text { Date }\end{array}$ & $\begin{array}{l}\text { Share } \\
\text { price } \\
\text { before } \\
\text { One day } \\
\text { of } \\
\text { restatem } \\
\text { ent } \\
\text { announc } \\
\text { ement }\end{array}$ & $\begin{array}{l}\text { Share } \\
\text { price } \\
\text { After } 5 \\
\text { days of } \\
\text { restatem } \\
\text { ent } \\
\text { announc } \\
\text { ement }\end{array}$ & $\begin{array}{l}\text { chan } \\
\text { ge } \\
\text { in } \\
\text { Shar } \\
\text { e } \\
\text { pric } \\
\text { e }\end{array}$ & $\begin{array}{l}\text { Tota } \\
1 \\
\text { Cha } \\
\text { nge }\end{array}$ & $\begin{array}{l}\text { Annua } \\
1 \\
\text { Correl } \\
\text { ation }\end{array}$ \\
\hline
\end{tabular}

The restatement types were examined by considering three main categories, as following;

1) Restatements arising from revenue recognition policies; involves errors or inconsistencies in the used approach, or calculation method used to recognize revenue. Furthermore, a reasonable number of these restatements that have 
originated due to issues like improperly considering sales contract rebate, resale cases or returns. Moreover, some of these cases may have emerged from transactions related to credit allowances, or sales returns (Audit Analytics, 2009).

2) Costs or expenses recognition policies; involves errors in the used approach, or in the method used to calculate expenses. These misstatements may occur due to factors like capitalizing some wrong expenses, or failure to comply with the matching principle (Audit Analytics, 2009).

3) Other issues; like Securities related, Assets Valuations, or related party transaction issues. These forms of misstatements that had to be adjusted by a financial restatement (Audit Analytics, 2009).

\subsubsection{Data gathered for the second assumption:}

The data gathered to analysis the second assumption can be divided in to two main parts;

1) The first part of the gathered data is collected from two studies that were conducted from the General Accounting Office(GAO*)

2) The second part of the data used has been gathered from yahoo finance website.

*GAO; is an independent agency that provides to the congress of the United States, investigative services that evolve mainly around audit evaluations (GAO, 2009).

However, to maintain an appropriate level of reliability in this study; some minor mathematical adjustments has to be done before performing the correlation analysis. Moreover, these adjustments have to be done in order to consider the percentage of change in the share price per each company. To figure out the amount of change between the price before one day of announcing a restatement, and after five trading days of the announcement then the difference is divided by the price before one day of announcing the restatement as following.

\section{Results and discussion}

\subsection{Results for first assumption}

The critical analysis of the first assumption can be divided in to two main steps; the first step was examining the relationship between external audit fees, and the count of internal controls deficiencies. Then the second main step was examining the relationship between external audit fees and the count of reported material weaknesses; because not all internal controls deficiencies would result in a material weakness (ACCA, 2009). Where by understanding how these two variables relate to each other; a much wider and a more constructive understanding of the relationship between these two variables can be concluded.

The graph below represents the relationship between these three variables; 


\section{Relation between External Audit fees, Material Weaknesses, \& Internal controls}

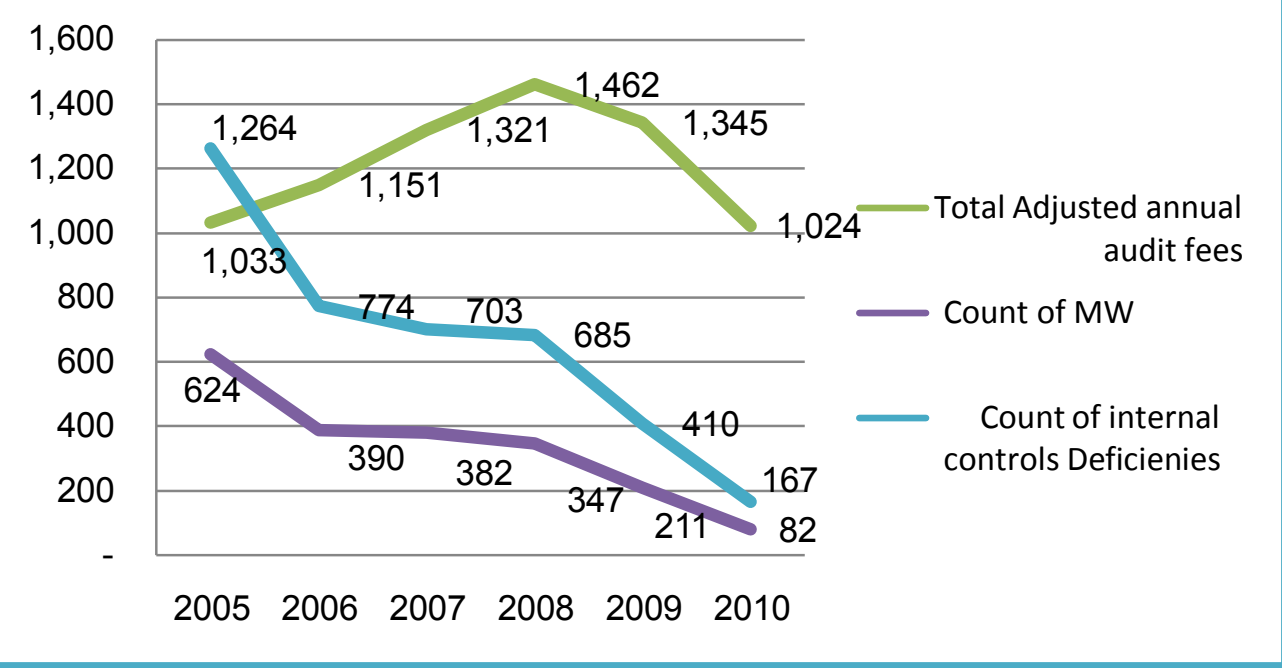

Through this graph it can be concluded that in 2005 "which is almost one year after implementing SOX 404 requirements" the relationship between these variables was negatively correlated. One of the main reasons behind this negativity is the extra time that external auditors had to spend on assessing and understanding the new set of internal controls. Furthermore, 2005 was the first year in which external auditors had to deal with such internal controls structure. The other main reason behind this strong negativity is that SOX 404 holds managers liable for any material weakness. Holding managers liable for the effectiveness of their internal controls, has forced them to act in a more responsible manner. So they would avoid any legal consequences of acting in an irresponsible way, or intentionally over riding their internal controls.

To get a deeper understanding about the relationship between these variables and external audit fees, a correlation analysis has been performed. The results of this correlation analysis that are shown in the below table which notes out the changes that happened in the relation between these examined variables for the period before and after the exemption;

\begin{tabular}{|c|c|c|c|c|}
\hline \multicolumn{3}{|c|}{ 2005-2007 Before Exemption } & \multicolumn{2}{|c|}{ 2008-2010 After Exemption } \\
\hline $\begin{array}{l}\text { Correlation } \\
\text { Analysis of } \\
\text { audit fees } \\
\text { with the } \\
\text { following } \\
\text { variables }\end{array}$ & $\mathrm{R}=$ & 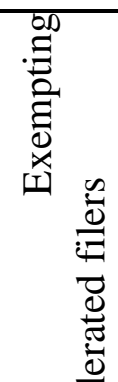 & $\begin{array}{l}\text { Correlation } \\
\text { Analysis of } \\
\text { audit fees } \\
\text { with the } \\
\text { following } \\
\text { variables }\end{array}$ & $\mathrm{R}=$ \\
\hline $\begin{array}{l}\text { Count of } \\
\text { MW }\end{array}$ & -0.82643 & 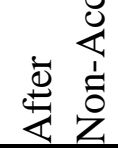 & $\begin{array}{l}\text { Count of } \\
\mathrm{MW}\end{array}$ & 0.96190 \\
\hline
\end{tabular}




\begin{tabular}{|c|c|c|c|}
\hline $\begin{array}{l}\text { Personal } \\
\text { Issues }\end{array}$ & -0.91629 & $\begin{array}{l}\text { Personal } \\
\text { Issues }\end{array}$ & 0.94326 \\
\hline $\begin{array}{l}\text { Segregation } \\
\text { Of Duties }\end{array}$ & -0.84525 & $\begin{array}{l}\text { Segregation } \\
\text { Of Duties }\end{array}$ & 0.94849 \\
\hline $\begin{array}{l}\text { financial } \\
\text { restatements }\end{array}$ & -0.92996 & $\begin{array}{l}\text { financial } \\
\text { restatements }\end{array}$ & 0.98009 \\
\hline $\begin{array}{l}\text { Material } \\
\text { Annual } \\
\text { Adjustments }\end{array}$ & -0.74184 & $\begin{array}{l}\text { Material } \\
\text { Annual } \\
\text { Adjustments }\end{array}$ & 0.94742 \\
\hline $\begin{array}{l}\text { Internal } \\
\text { Audit Issues }\end{array}$ & -0.11836 & $\begin{array}{l}\text { Internal Audit } \\
\text { Issues }\end{array}$ & 0.96589 \\
\hline $\begin{array}{l}\text { IT } \\
\text { Processing, } \\
\text { Access } \\
\text { Issues }\end{array}$ & -0.85081 & $\begin{array}{l}\text { IT } \\
\text { Processing, } \\
\text { Access Issues }\end{array}$ & 0.97232 \\
\hline
\end{tabular}

Through this correlation analysis the change in the relationship between the examined variables can be easily noticed. Where in the before exemption period; all the tested variables had a negative relationship with the external audit fees variable. Then after the exemption period this relationship as changed from being totally negative to totally positive. Where according to Spearman's rank; in the before exemption period the average correlation between all the above mentioned variables and external audit fees was a strong negative relationship of almost -0.73375 . Then after the exemption period the average correlation between all these variables and external audit fees have changed to become a very strong positive relationship of +0.95958 .

This massive change in the relationship between these variables have led to the conclusion that only one set of the examined variables have changed their behaviour while the other set of the variable remained constant. This enormous alteration in the form of the relationship between these examined variables have led to the conclusion that; after exempting non-accelerated filers from SOX 404 (B) the amount of their spending on external audit fees has massively declined in relation to the first three years of compliance. On the other hand, it can be noted also that the count of internal controls deficiencies and the count of reported material weaknesses has sustained a constant declining trend from 2005 till 2010. 


\subsection{Results for Second assumption}

Through the critical examination of the second assumption, it has been found that SOX 404 has achieved a positive change in investor's reactions towards financial restatements announcements. The below graph represents how the movement of the variables have changed during the before and after the implementation of SOX 404;

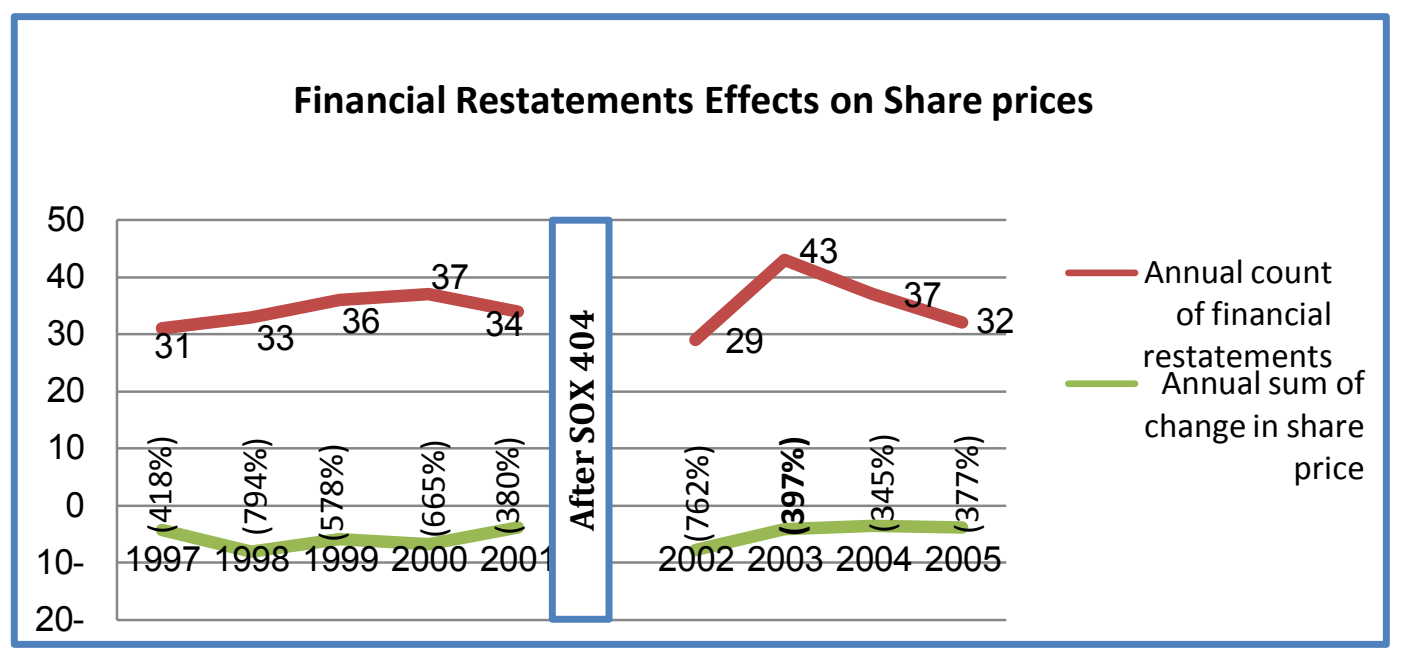

From the above graph it can be noted that in the period before implementing SOX 404 that these two variables were moving in an opposite direction or in other words they were negatively correlated. Where when a company announces a restatement from one side, the reaction from the other side will be a massive decrease in that company's share price. One of the main reasons for this movement would be due to the increase in the amount of risk that the investor would perceive that this company has. On the basis of this, investor's confidence about the reliability of the financial information communicated to them would start to decline. The matter that would be directly reflected as a decrease in the amount of demanded shares from that company. This decrease in demand will be faced with the exact same amount of offered shares, which eventually results in increasing the gap between what is offered and what is demanded, which eventually leads to a decrease in the share prices.

As for the after implementation period of SOX 404 it can be noticed that the relationship between the variables started to change, and investor's confidence started to get stronger. In order to get a wider understanding about the relationship between the variables have changed between the period before and after implementing SOX 404. A correlation analysis for the variables have been performed through which it has been found that according to Spearman's scale for the period before implementing SOX 404,the variables had a moderate negative correlation of -0.3262 . This negative correlation indicates that; when the count of announced financial restatements increases by 0.3262 , there will be a decrease of almost 0.3262 on the amount of demanded shares for that company.

\subsection{Conclusions for Second assumption}

As mentioned earlier all types of restatements have a negative effect on companies' share prices. But with the implementation of SOX 404 this negativity has been mitigated. Through 
this finding it can be concluded that investor's confidence has increased, nevertheless the count of financial restatements is still high in comparison to the period after SOX 404, which can be attributed to the increase in the number of filers.

\section{Recommendations}

SOX Act in general is one of the most important legislations in the $19^{\text {th }}$ century. Moreover, SOX 404 is considered to be the backbone of this Act that is why many studies have shown a lot of interest in understanding it and in evaluating its outcomes. Nevertheless, SOX 404 has been enforced more than ten years ago but there are still some crisp areas that can be further studied, especially since it is constantly developed, and some changes are constantly performed to make it more suitable for different sizes of companies.

One of the most recent changes applied to SOX 404 is the Dodd-Frank Act, which has a lot of areas that have not been studied like; how exemption non-accelerated filers from SOX 404 (B) would affect these filers competitiveness in the financial markets since they would be perceived as more risky companies to invest in. Other interesting topics to research in SOX 404 would be examining how would credit institutes likes "Banks", would react to financial restatements in the period before and after SOX, or how would they react to Dodd Frank Act.

Even the same assumptions that were examined in this paper can be further examined, or even re-examined from a different perspective.

For example in the first assumption, with further examination some other reasons besides the one that was concluded in this paper may be found. Where, this paper has found that one of the main the reasons that lead non-accelerated to sustain a constant declining trend in the reported internal controls deficiencies count is because these filers actually did not need all the parts of SOX 404. Where, with the implementation of SOX 404 (A) only, they managed to maintain this declining number of reported internal controls deficiencies. Moreover, in the second assumption that was made in this paper, rather than considering the share price change around the restatement announcement date; the volume of traded shares can be considered around the date of the restatement announcement.

\section{References}

Abdullah, H., Ahmad, Z. \& Roslam, S. (2012). The influence of ownership structure on the firms' dividend policy based on Lintner model. International Review of Business Research Paper, 8 (6)

Adeiza, M. K., Kabiru, I. D. \& Muhibudeen, L. (2015). Corporate shareholding structure and dividend payout ratio of listed chemical and paints companies in Nigeria. Applied Finance and Accounting, 1 (2)

Afzal, M. \& Sehrish, S. (2010). Ownership structure, board composition and dividend policy in Pakistan. COMSATS Institute of Information Technology, Islamabad-Pakistan

Al-Nawaiseh, M. (2013).Dividend policy and ownership structure: an applied study on 
industrial companies in Amman stock exchange. Journal of Management Research, 5 (2)

Azzam, I. (2010): The impact of institutional shareholders and dividend policy on stock return volatility: evidence from Egypt. International Journal of Business 15(4)

Bichara, L. Z. (2008).Institutional ownership and dividend policy: a framework based on tax clientele, information signaling and agency costs. University of North Texas, U.S.A.

Bradford, W., Chen, C. \& Zhu, (2006). Ownership structure, control chain and cash dividend: evidence from China. Centre for China finance and Business Research, California state University, U.S.A.

Chen, Z. H. Cheung, Y. Stouraitis A. \& Wong, A. (2005).Ownership concentration, firm performance and dividend policy in Hong-Kong, Pac. Bas. Finance. J., 13

Easterbrook, F. H. (1984). Two agency-cost explanation of dividends. The American Economics Review 74(4)

Eckbo, B. E. \& Verma, S. (1994). Managerial ownership, voting power and cash dividend policy. Journal of Corporate Finance 1, 33-62.

Beasley, M and Hermanson, D (2004) Going Beyond Sarbanes-Oxley Compliance: Five Keys to Creating Value. The CPA Journal [Online].Available from < http://www.nysscpa.org >

Bedard, J. (2006) Sarbanes-Oxley internal control requirements and earnings quality. Laval University.

Bonkim, J, Yeung, I, and Zhou, J. ( 2013) Material Weakness in Internal Control and Stock Price Crash Risk: Evidence from SOX Section 404 Disclosure The Accounting Review, pp.3-8.

Brorson, L (2012) the Sarbanes Oxley Act at Ernest and Young. Ernest and Young [Online].Available from :< http://www.ey.com

Brounstein, R (2005) committee on corporate reporting. Security Exchange commission [Online]. Available from < http:// www.sec.gov >

Brownlee, E (2007) Sarbanes-Oxley Section 404. Accountancy Ireland [Online].Available from : < http://www.accountancyireland.ie > [Accessed 08/03/2014].

D'Aquila, J. (2004) Tallying the Cost of the Sarbanes-Oxley Act. The CPA Journal [Online].Available from < http://www.nysscpa.org > [Accessed 29/01/2014].

Feng, M., and C. Li. (2011) Does SOX Section 404 Curb Material Misstatements? University of Pittsburgh, May, pp.32-35.

Hogan, C., and M. Wilkins. (2008) Evidence on the audit risk model: Do auditors increase audit fees in the presence of internal control deficiencies? Contemporary Accounting Research, 25 Jan, pp. 219-242.

Hoitash, R., U. Hoitash, and J. Bedard. (2008) Internal Control Quality and Audit Pricing 


\section{Macrothink}

International Journal of Accounting and Financial Reporting

ISSN 2162-3082

2016, Vol. 6, No. 1

under the Sarbanes-Oxley Act. Auditing: A Journal of Practice and Theory, 27, pp.105-126.

Lee, S. Wang, H. and others.(2005) Summary of key points from submissions to the SEC. KPMG [Online], April, pp.1-10. Available from:<http://www.kpmg.com. $>$

McCrary, A. (2010). Mastering Corporate Finance Essentials [Electronic Resource] : The Critical Quantitative Methods And Tools In Finance, Hoboken: John Wiley \& Sons, Inc., 2010. Available from: Leeds Metropolitan University Library Catalogue.

Nagy, A. (2010) Section 404 Compliance and Financial Reporting Quality. Accounting Horizons 24, pp. 441-454.

PCAOB, [2007] Release No. 2007-005A. PCAOB [Online].Available from :< http://www pcaobus.org >

Qian, J., P. Strahan, J. Zhu. (2010)The economic benefits of the Sarbanes-Oxley Act? Evidence from a natural experiment Boston College.

Raghunandan, K., and D. Rama (2006). SOX Section 404 material weakness disclosures and audit fees. Auditing: A Journal of Practice \& Theory 25 (1) pp. 99-114.

Rice, S, and Weber, D. (2011). How effective is Internal Control Reporting under SOX 404 ? Determinants of the (Non-) Disclosure of Existing Material Weaknesses. Journal of Accounting Research [Online].Available from : $\langle$ http://www.journalofaccountancy.com $>$

Rice,C. and Weber, P. and Wu, u. (2013). Does SOX 404 Have Teeth? Consequences of the Failure to Report Existing Internal Control Weaknesses.

Scholz, S (2008). The changing nature and consequences of public company financial restatements. The department of treasury [Online].Available from :< http://www.treasury.gov >

SOX-Online (2003) Sarbanes-Oxley Essential Information [Online]. Available from: http://www.sox-online.com> [Accessed 27/12/2013].

SOX-Online (2003) Section 302 of the Sarbanes-Oxley Act [Online].Available from : www.dealbook.nytimes.com>

Thornton, B, and He, L (2013) the Impact of Disclosures of Internal Control Weaknesses and Remediation on Investors' Perceptions of Earnings Quality. Accounting Perspectives, 12, pp. $2-16$.

Tysiac, k. (2012) corporate governance best practices 10 years after SOX. Journal of Accountancy [Online].Available from $:<\mathrm{http}: / / \mathrm{www}$.journalofaccountancy.com 